\title{
Evaluation of Different Planting Technique in Ratoon Sugarcane under Semi-Arid Conditions
}

\author{
Muhammad Mohsin Raza ${ }^{1 *}$, Hera Gul², Malik Muhammad Yousaf ${ }^{1}$, Sami Ullah ${ }^{3}$, Ghulam Sabir Hussain ${ }^{4}$, \\ Mumtaz Hussain ${ }^{1}$, Jahangir Shah ${ }^{1}$, Bashir Ahmad ${ }^{1}$, Rao Wali Muhammad ${ }^{1}$ Ijaz Ahmad ${ }^{5}$ and Muhammad \\ Zeshan $^{6}$
}

${ }^{1}$ Pakistan Agricultural Research Council Arid Zone Research Institute, Bahawalpur, Pakistan; ${ }^{2}$ Department of Horticultural Science, Faculty of Agriculture and Environmental sciences, The Islamia University of Bahawalpur, Pakistan; ${ }^{3}$ Department of Biology University of Okara, Okar Pakistan; ${ }^{4}$ Department of Agronomy Bahuddin Zakriya University Multan; ${ }^{5}$ Ecotoxicology Research Program, National Agriculture Research Canter Islamabad, Pakistan; ${ }^{6}$ National Institute for genomic and advance biotechnology NARC, Islamabad, Pakistan.

Abstract | Effect of different planting patterns on the productivity of first ratoon of sugarcane genotype SPSG-394 was determined under field condition throughout the year 2017-18. Planting patterns under study comprised $100 \mathrm{~cm}$ spaced $30 \mathrm{~cm}$ wide single row ditches, $100 \mathrm{~cm}$ spaced $60 \mathrm{~cm}$ wide double row ditches, $100 \mathrm{~cm}$ spaced $90 \mathrm{~cm}$ wide triple row ditches, $100 \mathrm{~cm}$ spaced $100 \times 100 \mathrm{~cm}$, pits, $90 \mathrm{~cm}$ spaced single rows and $90 \mathrm{~cm}$ spaced double row strips. The quadruplicated experiment already laid out according to RCBD for the plant crop, used for this study. The sugarcane was sown on September 8 2015, and in late February, 2017 it was harvested. Consequent ratoon was the test crop. The latter was harvested on $16^{\text {th }}$ of February, 2018. Observation on different qualitative and quantitative traits of crop were recorded by using standard procedure. Highest number of millable cane $\mathrm{m}^{2}(10.35)$ was recorded for sugarcane planted in 100 $\mathrm{cm}$ spaced and $90 \mathrm{~cm}$ wide triple against the lowest of $8.55 \mathrm{cane}^{2}$ for that planted in $100 \mathrm{~cm}$ spaced and $30 \mathrm{~cm}$ wide single row ditches. The highest stripped cane yield was obtained from sugarcane planted in 100 $\mathrm{cm}$ spaced $60 \mathrm{~cm}$ wide double row ditches $\left(75.03 \mathrm{t} \mathrm{ha}^{-1}\right)$ while the lowest from that planted in $90 \mathrm{~cm}$ spaced single rows. Planting pattern did not significantly impact on sucrose $\%$ of cane juice that however range between 20.56 and $20.03 \%$. The highest harvest index of $79.21 \%$ was recorded for sugarcane planted in $100 \mathrm{~cm}$ spaced $30 \mathrm{~cm}$ wide single row ditches.

Received | November 14, 2020; Accepted | January 14, 2021; Published | March 23, 2021

*Correspondence | Muhammad Mohsin Raza, Pakistan Agricultural Research Council Arid Zone Research Institute, Bahawalpur, Pakistan; Email: mohsinraza@parc.gov.pk

Citation | Raza, M.M., H. Gul, M.M. Yousaf, S. Ullah, G.S. Hussain, M. Hussain, J. Shah, B. Ahmad, R.W. Muhammad, I. Ahmad and M. Zeshan. 2021. Evaluation of different planting technique in ratoon sugarcane under semi-arid conditions. Pakistan Journal of Agricultural Research, 34(2): 254-258.

DOI | http://dx.doi.org/10.17582/journal.pjar/2021/34.2.254.258

Keywords | Ratoon, Sugarcane, Planting pattern, Plant Productivity

\section{Introduction}

Gugarcane (Saccharum Officinarum L.) is a prominent $N_{\text {member of the large family of grasses. Basically }}$ it is cultivated in tropics but its cultivation has been extended to subtropical regions between altitude $30^{\circ} \mathrm{N}$ and $35^{\circ} \mathrm{S}$. In subtropical region of Pakistan, sugarcane is being grown successfully only under irrigated conditions. Sugarcane has a central role in country economy due to its cash crop in nature. It plays vital role in economic uplift of grower as well as country. It provides basic raw material for domestic 
industry. Being a perennial crop, sugarcane is capable of growing successfully as ratoon crop for several years if managed properly and looked after carefully. At farmer's field the ratoon sugarcane yield has always been less than that of plant crop (U1lah et al., 2016; Raza et al., 2016).

Main reason for low cane yield in Pakistan is low soil fertility, suboptimal plant population density, poor management and inappropriate plating method for efficient utilization of natural resources (Anjum et al., 2015). It is well established that fertilization has a key role in sustaining crop productivity (Ullah et al., 2019; Zhang et al., 2019; U1lah et al., 2020a, b) however appropriate plant method also played an important role particularly in sugarcane. Conventional method of planting sugarcane in $60 \mathrm{~cm}$ spaced single row limits domestic cane production to considerable extent (Shafi et al., 1990).

The newly developed methods have been reported to different production positional. Crop planted in $60 \mathrm{~cm}$ wide ditches with double row have been reported to give the maximum cane yield (Mahmood, 1997). As there are limited literature on the performance of ratoon sugarcane crop at newly developed plantation techniques, this study was designed to investigate the effect of different planting patterns on ratooning ability and production positional of the sugarcane genotypes SPSG-394 as first spring ratoon crop under the agro-ecological condition of Faisalabad.

\section{Materials and Methods}

The proposed study was established at the Agronomic Research area, University of Agriculture, Faisalabad during 2017-18. The experiment was undertaken according to randomized complete block design for the plant crop that kept as ratoon for study. The net plot size was variable for each treatment. However, a uniform area from each experiment unit was harvested for recording the data. The treatment comprised the following six planting patterns. T1: $100 \mathrm{~cm}$ spaced 30 $\mathrm{cm}$ single row ditches and T2: $100 \mathrm{~cm}$ spaced and 60 $\mathrm{cm}$ wide double row ditches $T 3: 100 \mathrm{~cm}$ spaced $90 \mathrm{~cm}$ wide triple row ditches and $T 4: 100 \mathrm{~cm}$ spaced and $100 \times 100 \mathrm{~cm}$ pits, T5: $90 \mathrm{~cm}$ spaced double row strips (30/90 cm), T6:90 cm spaced single rows. Sugarcane genotype SPSG-394 was sown as plant crop. The plant crop was harvested at the end of February 2017and was kept as ratoon for the present study. After harvesting the plant crop trash was removed from field and weeds were controlled by manual hoeing in order to encourage sprouting of stubbles of the plant crop. Fertilizer was applied @220-110-110kg N, $\mathrm{P}_{2} \mathrm{O}_{5} \mathrm{~K}_{2} \mathrm{O}$ $\mathrm{ha}^{-1}$ in the form of urea,TSP and SOP. Whole of the phosphorous, potash and half of nitrogen applied after sprouting of plant crop. The nitrogen which was left was applied at tillering stage (30 days after the first application of fertilizer). Total of 16 irrigations, each of $10 \mathrm{~cm}$, were given to crop. Beside of $604.7 \mathrm{~mm}$ rainfall received during growth period of crop. The crop was harvested on $16^{\text {th }}$ of February 2018. The following observation were recorded at the time of crop harvest.1: Number of millable canes $\mathrm{m}^{-2}$, cane length in meter, cane diameter in $\mathrm{cm}$, number of inter node per cane, internodes length $\mathrm{cm}$, weight per stripped cane $\mathrm{kg}$, tops weight $\left(\mathrm{t} \mathrm{h}^{-1}\right)$, Trash weight $\left(\mathrm{t} \mathrm{ha} \mathrm{a}^{-1}\right)$, stripped cane yield $\left(\mathrm{t} \mathrm{ha} \mathrm{h}^{-1}\right)$, sucrose content $\%$, commercial cane sugar $\%$ and harvest index $\%$. Data collected were subjected to Fisher's analysis of variance technique and the treatment means were compared by using the LSD test at 0.05 probability level (Steel and Torrie, 1984).

\section{Results and Discussion}

The number of mill able cane $\mathrm{m}^{-2}$ is the major yield component which play key role in formulating the final cane yield $\mathrm{ha}^{-1}$. The statically analysis of data reveal that there was highly significant difference in number of mill able cane among the different planting pattern. The highest number of mill able cane $\mathrm{m}^{-2}$ was recorded in crop grown in T1 (10.35) which was however statically equal that planted T3 (10.31) and T2 (10.28a). On contrary the lowest number of mill able cane $\mathrm{m}^{-2}(8.55 \mathrm{~b})$ was produced by crop raised in T1 and T6 (8.7). Differential effect of different planting pattern on the number of mill able cane $\mathrm{m}^{-2}$ might be attributed to the varying germination count and till ring. Earlier studies also confirmed same results (Nazir et al., 1988). The data regarding the cane length are given in Table 1. The result shows that significant difference in cane length among different planting pattern. The T3 show maximum cane length (2.11a) and minimum cane length were produced by T6. The maximum cane length in T3 owing to enhanced utilization of nutrients and water for development of cane because of adequate availability of growth resources in this planting techniques. These finding are agreement with (Anjum et al., 2015). Cane diameter is another 
important yield contributing component of sugarcane .it is effected by the environment to which the plant is exposed during it growth period. The results presented in Table 1 clearly indicated that a distinct difference was found among the various planting pattern but these difference were not large enough to reach the level of significance however, on an average the cane diameter ranged between $2.00 \mathrm{~cm}$ to $2.11 \mathrm{~cm}$. These results concur with finding of (Randhawa et al., 1993), demonstrated that different row spacing had no significant effect on cane diameter. The number of internodes with inter nodal length determine the cane length which ultimately contribute towards the final cane yield $\mathrm{ha}^{-1}$ the data given in Table 1 indicate that there were significant difference among the different planting technique. Sugarcane planted in T6 show greatest number of internodes (19.57) but did not differ significantly from that planted in T6 (19.54) and T3 (18.74) Internodes per cane. On contrary the lowest number of internodes per cane (17.27) were recorded from $\mathrm{T} 5$ which was however statically equal to that in T4 (17.92) and T2 (18.35). Similar result has been reported by (Bashir, 1995), showed that sowing pattern had a significant effect on number of internodes. Intermodal length has significant effect on sugarcane yield. The data presented in Table 1 indicate that planting technique had highly significant effect on intermodal length. The maximum intermodal length (11.34) was recorded in T4 which in turn statically equal to $\mathrm{T} 3$ and $\mathrm{T} 2$. In contrary the shortest inter node $(10.08 \mathrm{~cm})$ was produced by the sugarcane planted in T6. Longer internodes in pit plantation as well as in double and triple row ditches then other treatment might be due to accelerated growth rate because of less light penetration in to crop canopy and more availability of water and its efficient utilization by the crop in the former three planting technique as both shades/ darkness (Afghan, 1996) and adequate water supply (Bashir, 1995) promote stem elongation. The individual cane biomass has a direct bearing on the final cane yield and is function of combined effect of thickness of cane. The data presented in Table 6 indicate that there were significant difference among the various planting pattern the maximum cane weight was observed in T2 (0.75) and in contrast the lowest weight per stripped cane was obtain in T6 $(0.58 \mathrm{~kg})$ similar result have also been reported by (Anjum et al., 2015). The data regarding tops weight $\mathrm{t} \mathrm{ha} \mathrm{a}^{-1}$ are presented in Table 1 there was highly significant difference among the various treatment under study. Maximum weight of the top $\left(15.91 \mathrm{tha}^{-1}\right)$ was obtained in T4. On contrary the lowest top weight $\left(9.51 \mathrm{t} \mathrm{ha}^{-1}\right)$ was recorded in $\mathrm{T} 1$. The data regarding trash weight per $\mathrm{ha}^{-1}$ as influenced by different planting pattern are given in Table 1 . The maximum trash weight was recorded in T3 (8.14) which were at par with T4 (8.12). On contrary the lowest trash weight (4.97 t $\mathrm{ha}^{-1}$ ) was recorded from T5 similar result have been reported by (Ullah et al., 2016) strip cane yield per hectare is a function of the interplay of various yield parameters. The data on strip cane yield presented in Table 1 . There were highly significant differences among the different planting pattern the sugarcane planted T2 (75.03) Produced the highest striped cane yield but statically equal to that in T4 $\left(73.09 \mathrm{t} \mathrm{ha}^{-1}\right)$. On contrary the lowest yield was obtain T6 (46.7 t $\mathrm{ha}^{-1}$ ) above result concur with the finding of (Ullah et al., 2016). The highest striped cane yield in case of T2 was attributed to greater number of mill able cane and relatively higher cane weight. Once cane is matured its quality are mainly evaluated by sugarcane juice sucrose content. The sucrose content in cane juice presented in Table 1. Although there were visible differences among different planting pattern but these differences were not large enough to reach the level of significance however sucrose content range between 20.56-20.03\%.

Table 1: Treatments.

\begin{tabular}{|c|c|c|c|c|c|c|c|c|c|c|c|c|}
\hline $\begin{array}{l}\text { Treat- } \\
\text { ment }\end{array}$ & $\begin{array}{l}\mathrm{MC} \\
\mathbf{m}^{-2}\end{array}$ & $\begin{array}{l}\text { CL } \\
(\mathrm{m})\end{array}$ & $\begin{array}{l}\text { CD } \\
(\mathrm{cm})\end{array}$ & INPC & $\begin{array}{l}\text { IL } \\
(\mathrm{cm})\end{array}$ & $\begin{array}{l}\text { CW } \\
(\mathbf{k g})\end{array}$ & $\begin{array}{l}\text { WT } \\
\left(\text { tha }^{-1}\right)\end{array}$ & $\begin{array}{l}\text { TW } \\
\text { t ha }^{-1}\end{array}$ & $\begin{array}{l}\text { SCY } \\
\text { tha }^{-1}\end{array}$ & $\begin{array}{l}\text { SC } \\
(\%)\end{array}$ & $\begin{array}{l}\text { CCS } \\
\text { (\%) }\end{array}$ & $\begin{array}{l}\text { HI } \\
(\%)\end{array}$ \\
\hline $\mathrm{T} 1$ & $8.55 b$ & $2.02 \mathrm{ab}$ & $2.08^{\mathrm{NS}}$ & $19.54 \mathrm{a}$ & $10.20 \mathrm{~b}$ & $0.66 c$ & $9.51 \mathrm{~d}$ & $4.99 c$ & $52.55 \mathrm{c}$ & $20.50^{\mathrm{NS}}$ & $15.63^{\mathrm{NS}}$ & $79.21 \mathrm{a}$ \\
\hline $\mathrm{T} 2$ & $10.28 \mathrm{a}$ & $2.05 \mathrm{ab}$ & 2.11 & $18.35 b c$ & $11.26 \mathrm{a}$ & $0.75 \mathrm{a}$ & $13.58 \mathrm{~b}$ & $7.21 \mathrm{~b}$ & $75.03 \mathrm{a}$ & 20.35 & 15.82 & $78.27 \mathrm{ab}$ \\
\hline T3 & $10.35 \mathrm{a}$ & $2.11 \mathrm{a}$ & 2.04 & $18.74 \mathrm{ab}$ & $11.32 \mathrm{a}$ & $0.68 b c$ & $14.03 \mathrm{~b}$ & $8.14 \mathrm{a}$ & $65.54 \mathrm{~b}$ & 20.56 & 15.93 & $74.69 \mathrm{~d}$ \\
\hline $\mathrm{T} 4$ & $10.31 \mathrm{a}$ & $2.03 \mathrm{ab}$ & 2.11 & $17.92 \mathrm{bc}$ & $11.34 \mathrm{a}$ & $0.73 \mathrm{ab}$ & $15.91 \mathrm{a}$ & $8.12 \mathrm{a}$ & $73.09 \mathrm{a}$ & 20.23 & 15.49 & $75.27 \mathrm{~cd}$ \\
\hline T5 & $8.81 b$ & $1.99 \mathrm{bc}$ & 2.00 & $17.27 \mathrm{c}$ & $10.14 \mathrm{~b}$ & $0.63 \mathrm{~cd}$ & $10.61 \mathrm{c}$ & $4.68 c$ & $50.98 \mathrm{~cd}$ & 20.3 & 15.35 & $76.93 \mathrm{bc}$ \\
\hline T6 & $8.70 \mathrm{~b}$ & $1.90 \mathrm{c}$ & 2.00 & $19.57 \mathrm{a}$ & $10.08 \mathrm{~b}$ & $0.58 \mathrm{~d}$ & $9.81 \mathrm{~cd}$ & $4.97 \mathrm{c}$ & $46.70 \mathrm{~d}$ & 20.52 & 17.85 & $75.92 \mathrm{~cd}$ \\
\hline
\end{tabular}

Note: MC: Mill able Cane; CL: Cane Length; CD: Cane Diameter; INPC: No. of internodesper cane; IL: Intermodal length's= Cane weight; WT: Weight of tops; TW: Trashs Weight; SCY: Stripped cane yield; SC: Sucrose content; CCS: Commercial cane sugar; HI: Harvest index. 
These finding are in consistent with the finding of (Singh et al., 1987). The data regarding the commercial cane sugar percentage are presented in Table 1. Planting technique had non-significant effect on C.C.S \%. However, the C.C.S percentage varied from 15.35 to 15.93 . The non significant differences among all the planting patterns were probably attributed to the uniform cane maturity in all treatment. These finding are similar to those of (Ullah et al., 2016) clearly established their findings that row spacing failed to impact cane quality. Harvest index express the efficiency of the crop for production of its economic parts. There were highly significant differences in harvest index among various planting technique. Harvest index was maximum (79.21\%) when sugarcane was planted in T1and statically equal to T2 $(78.27 \%)$. On contrary the lowest harvest index was recorded (74.69\%) T3 did not differ from crop raised inT 6 and $\mathrm{T} 4$.

\section{Novelty Statement}

To the best of our knowledge this is the first study conducted on Ratoon Sugarcane under semi-arid condition.

\section{Author's Contribution}

Muhammad Mohsin Raza: Conceived the idea.

Hera Gul: Wrote abstract

Malik Muhammad Yousaf: Planned methodology

Sami Ullah and Rao Wali Muhammad: Did SPSS analysis.

Ghulam Sabir Hussain: Concluded the research. Mumtaz Hussain: Provided technical input at every step.

Jahangir Shah: Overall management of the article.

Bashir Ahmad: Collected the data.

Ijaz Ahmad: Wrote results and discussion.

Muhammad Zeshan: Wrote introduction and managed references.

\section{Conflict of interest}

The authors have declared no conflict of interest.

\section{References}

Afghan, S., 1996. Impact of planting patterns and nutrient management on agro-physiology of sugarcane, Doctoral dissertation, Ph. D. thesis, Dept. Agron., Univ. of Agric., Faisalabad.
Anjum, S.A., M. Raza, N. Hussain, M. Nadeem and N. Ali. 2015. Studies on productivity and performance of spring sugarcane sown in different planting configurations. Am. J. Plant Sci., 6(19): 2984. https://doi.org/10.4236/ ajps.2015.619293

Bashir, G.M., 1995. Physio-agronomic studies on flat versus pit plantation of autumn and spring sugarcane (Saccharum Officinarum L.), Doctoral dissertation, University of Agriculture Faisalabad Pakistan.

Devi, C., K.L. Rao and D.V.M. Raju. 1990. Studies on the effect of row space and nitrogen on yield and quality of early maturing sugarcane varieties. Indian Sugar, 40(7): 541-544.

Mahmood, A., 1997. Production potential and juice quality of autumn sugarcane as influence by different planting patterns. Master's thesis, M. Sc thesis, Dept. Agron., Univ. Agric., Faisalabad.

Mali, A.L. and P.P. Singh. 1985. Quality of Sugercane as influenced by varities in relation to varying row spacing. Indian Sugar, 35(8): 451-456. https://doi.org/10.4259/ibk.35.456

Nazir, M.S., I.A. Fageer, G. Ali, R. Ahmad and T. Mahmood.1988. Studies on planting and intercropping in autumn sugarcane. Gomal Univ. J. Res., 8(1-2): 57-64.

Randhawa, M.A., S.A. Khan, K.M. Chaudhry, M.S. Nazir and M.Y. Khan. 1993. Effect of planting techniques on the yield and quality of autumn sugarcane at different plant populations. Pakistan Sugar J.,, 7: 7-10.

Raza, M.M., S. Ullah, Z. Ahmad, S. Saqib, S. Ahmad, H.M. Bilal and F. Wali. 2016. Silicon mediated arsenic reduction in rice by limiting its uptake. Agric. Sci., 7(01): 1. https://doi. org/10.4236/as.2016.71001

Shafi, M., M.L. Shah, T. Mahmood, S. Afghan and S.H. Shah. 1990. Cane yield and quality of sugarcane as influenced by different planting patterns. Pak. Sugar. J., 4(2): 3-4.

Singh, V.P., K.C. Jha and S. Zaman. 1987. Effect of seed rate, spacing and nitrogen on the yield and quality of sugarcane under late sown conditions in North Bihar. Indian Sugar Crops J., 13(4): 14-18.

Steel, R.D.G. and J.H. Torrie. 1984. Principales and procedures of statistics: A biometrical approach, $4^{\text {th }}$ print.

Ullah, S., S.A. Anjum, M.M. Raza, A. Riaz, 
A. Abbas, M.M. Yousif and Y. Xu. 2016. Optimizing row spacing to ameliorate the productivity of spring sugarcane (Saccharum officinarum L.). Agric. Sci., 7(08): 531. https:// doi.org/10.4236/as.2016.78053

Ullah, S., C. Ai, W. Ding, R.Jiang, S. Zhao,J.Zhang and P. He. 2019. The response of soil fungal diversity and community composition to longterm fertilization. Appl. Soil Ecol., 140: 35-41. https://doi.org/10.1016/j.apsoil.2019.03.025

Ullah, S., C. Ai, S. Huang, D. Song, T. Abbas, J. Zhang and P. He. 2020a. Substituting ecological intensification of agriculture for conventional agricultural practices increased yield and decreased nitrogen losses in North
China. Appl. Soil Ecol., 147: 103395. https:// doi.org/10.1016/j.apsoil.2019.103395

Ullah, S. H. Ping, A. Chao, Z. Shicheng, D. Wencheng, S. Dali, Z. Jiajia, H. Shaohui, A. Tanveer and Z. Wei. 2020b. How do soil bacterial diversity and community composition respond under recommended and conventional nitrogen fertilization regimes? Microorganisms 8(8): 1193. https:// doi.org/10.3390/microorganisms8081193

Zhang, J., P. He, W. Ding, X. Xu, S. Ullah, T. Abbas and W. Zhou. 2019. Estimating nutrient uptake requirements for radish in China based on QUEFTS model. Sci. Rep., 9(1): 1-10. https:// doi.org/10.1016/j.physrep.2019.10.003 